\title{
Carcinoid daganatok
}

\author{
Pregun István dr. ${ }^{1}$ - Bodoky György dr. ${ }^{2}$ \\ Rácz Károly dr. ${ }^{1}$ - Tulassay Zsolt dr. ${ }^{1}$
}

${ }^{1}$ Semmelweis Egyetem, Általános Orvostudományi Kar, II. Belgyógyászati Klinika, Budapest ${ }^{2}$ Fővárosi Önkormányzat Szent László Kórház, Onkológiai Osztály, Budapest

\begin{abstract}
A szerzők a carcinoid tumorokkal kapcsolatos legfontosabb klinikai gyakorlati ismeretekról adnak áttekintést. A carcinoid daganatok neuroendokrin sejtekből származó, többségében lassan növekvő ritka tumorok, azonban gyorsan metasztatizáló, agresszív formában is jelentkezhetnek. Epidemiológiai adatok szerint gyakoriságuk nő, amit részben a diagnosztikus módszerek fejlődése okozhat. A daganatok gyakran tünetmentesek, máskor carcinoid szindróma vagy egyéb endokrin szindrómák tünetei lehetnek jelen. A korai diagnózist biokémiai markerek (szérumkromogranin-A, vizelet-5-hidroxi-indolecetsav) és speciális képalkotó módszerek segítik. A daganatok jelentős részét a betegség előrehaladott stádiumában ismerik fel; ezekben az esetekben sebészi módszerekkel nem érhető el teljes gyógyulás, bár a daganat megkisebbítésének sebészi vagy intervenciós radiológiai lehetőségeit ilyenkor is számításba kell venni. A carcinoid tumorokhoz társuló klinikai tünetek kezelésének jelenleg leghatásosabb eszközei a szomatosztatin-analóg készítmények, amelyek a tünetek megszüntetésén/enyhítésén kívül tumorgátló hatásuk révén akár hosszú éveken keresztül kivédhetik a daganatok növekedését vagy ritkán daganatregressziót válthatnak ki. A kemoterápiás készítményeket elsősorban metasztatikus, agresszív, gyorsan növekvő, illetve pancreas neuroendokrin daganatok esetén alkalmaznak, klinikai vizsgálatokban új kemoterápiás lehetőségként a temozolomid és a thalidomid adásával szereztek kedvező kezdeti tapasztalatokat. Progresszív, előrehaladt stádiumú daganatban szenvedő betegek részére hatékony új terápiás lehetőség a ${ }^{131} \mathrm{I}-\mathrm{MIBG},{ }^{90}$ Y-DOTA-TOC és ${ }^{177} \mathrm{Lu}$-DOTA-TOC radionuklid kezelés. Kezdeti tapasztalatok állnak rendelkezésre a tirozinkináz-gátlók, tirozinkináz-ellenes antitestek és a „mammalian target of rapamycin” (mTOR) gátlók alkalmazásáról, amelyek közül a hatékonynak bizonyuló készítmények a jövőben szélesebb körű alkalmazást nyerhetnek. Orv. Hetil., 2010, 46, 1885-1894.
\end{abstract}

Kulcsszavak: carcinoid tumorok, neuroendokrin tumorok, kromogranin-A, 5-hidroxi-indolecetsav, szomatosztatinanalógok

\section{Carcinoid tumors}

The authors review the most important clinical aspects of carcinoid tumors. Carcinoid tumors originating in neuroendocrine cells are rare, usually slowly-growing neoplasms, however, they may present as aggressive and rapidly progressing tumors. Epidemiologic data indicates that their prevalence is gradually increasing, which may be explained, at least in part, by the development and wider use of advanced diagnostic methods. A considerable proportion of patients with neuroendocrine tumors are symptom-free, whereas others may have carcinoid syndrome or symptoms of other endocrine syndromes. Early diagnosis may be established by the measurement of biochemical markers (serum chromogranin A, urinary 5-hydroxyindoleacetic acid) and advanced localization methods. A considerable number of patients are diagnosed at the late stages of the disease; in these cases surgical cure is not possible but surgical and/or interventional radiologic procedures which reduce tumoral mass should be still considered. The most effective drugs for symptomatic treatment of carcinoid tumors are somatostatin analogues; in addition to their beneficial effect on clinical symptoms they may stabilize tumor growth for many years and, less frequently, may produce tumor regression. The use of chemotherapeutic agents is considered in patients with aggressive, rapidly growing and advanced tumors; initial findings with temozolomide and thalidomide in clinical trials raise the possibility that these chemotherapeutic agents may prove to be new therapeutic options. Radioisotope-labeled peptide receptor therapy with ${ }^{131} \mathrm{I}$-MIBG, ${ }^{90} \mathrm{Y}$-DOTA-TOC or ${ }^{177} \mathrm{Lu}$-DOTA-TOC may offer a highly effective option for patients with progressive and advanced stage of neuroendocrine tumors. Initial observations obtained in clinical trials with some 
tyrosine kinase inhibitors, antibodies against tyrosine kinases, and with inhibitors of mammalian target of rapamycin (mTOR) support the possibility that at least some of these new agents may have a role in future treatment options in patients with advanced neuroendocrine tumors. Orv. Hetil., 2010, 46, 1885-1894.

Keywords: carcinoid tumors, neuroendocrine tumors, chromogranin A, 5-hidroxyindoleacetic acid, somatostatin analogues

(Beérkezett: 2010. szeptember 27.; elfogadva: 2010. október 15.)

\begin{abstract}
Rövidítések
APUD-sejt = aminprekurzor-felvételre és dekarboxilációra képes sejt; $\mathrm{CgA}=$ kromogranin-A; $\mathrm{CE}$ = kapszulaendoszkópia; $\mathrm{EC}=$ enterokromaffin; $\mathrm{ECL}=$ enterokromaffinszerü; EGF = epidermalis növekedési faktor; EUS = endoszkópos ultrahang; GEP-NET = gastroenteropancreaticus neuroendokrin tumor; 5-HIAA = 5-hidroxi-indolecetsav; IGF-I = inzulinszerú növekedési faktor I; MEN-1 = multiplex endokrin neoplasia l-es típusa; $\mathrm{MIBG}=$ metajódbenzilguanidin; $\mathrm{mTOR}=$ mammalian target of rapamycin; NE = neuroendokrin; NET = neuroendokrin tumor; NFl = neurofibromatosis 1 -es típusa; PDGFR = platelet-derived growth factor receptor; $\mathrm{PET}=\mathrm{po}^{-}$ zitronemissziós tomográfia; PPI = protonpumpagátló; PSA = prosztataspecifikus antigén; SEER-vizsgálat = Surveillance Erpidemiology and End Results vizsgálat; SIADH = vazopreszszintúltermelés-szindróma; SRS = szomatosztatinreceptor-szcintigráfia; SSA = szomatosztatin-analóg; TACE = transarterialis kemoembolizáció; TGF- $\alpha=$ transzformáló növekedési faktor- $\alpha$; VEGF = vascular endothelial growth factor; WHO = World Health Organization; ZES = Zollinger-Ellison-szindróma
\end{abstract}

A neuroendokrin (NE) sejtek a szervezetben számos helyen megtalálhatók, elsősorban a gyomor-bél rendszerben, hasnyálmirigyben, tüdóben és az urogenitalis rendszerben. Jellemzőjük, hogy intracitoplazmatikus granulumokat tartalmaznak, különböző biogén aminokat, peptideket termelnek, s a sejtekból kiinduló daganatok jellegzetes klinikai és patológiai sajátságokkal bírnak.

A „neuroendokrin daganat” (NET) kifejezés kizárólag a daganat eredetére utal: az elnevezés valójában heterogén csoportot takar, hiszen a daganatok klinikai megjelenése, viselkedése és a kórlefolyás több tekintetben eltérő lehet. A „carcinoid” („karzinoide”) elnevezés Sigfried Oberndorfer nevéhez köthető, aki 1907-ben egy „karcinomaszerü” vékonybéldaganatot jelölt a kifejezéssel. A klinikai lefolyás ugyanis benignusnak tünt, azonban a szövettani vizsgálat malignus daganatot jelzett. 1948-ban Rapport és munkatársai fedezték fel a vasoconstrictor hatású szerotonint, 1952-ben pedig kimutatták, hogy ez a biogén amin a Kulchitsky-sejtböl származik. Egy évvel később Lembeck ilealis carcinoidban bizonyította a szerotonintermelést, s ezzel hozta összefüggésbe a carcinoid szindrómára jellemző tüneteket. 1969-ben Pearse írta le az „APUDomát”, amely aminprekurzor-felvételre és dekarboxilációra (amine precursor uptake and decarboxylation) képes sejtekből származik. Bizonyítást nyert az is, hogy ezek a sejtek olyan hormonokat, peptideket termelnek, amelyek a ne- uronokban is megtalálhatók [1]. A „neuroendokrin tumor" koncepciót ezek a felismerések alapozták meg.

\section{Osztályozás}

A „neuroendokrin tumor (NET)”, „gastroenteropancreaticus neuroendokrin tumor (GEP-NET)” és „carcinoid" elnevezéseket évtizedekig szinonimaként használták az irodalomban, ami számos esetben bonyolulttá tette, nehezítette a megértést. A daganatok első osztályozása Williamstől és Sandlertől származik, a beosztás az embrionális eredetet alapul véve előbél-, középbél- és hátsóbél-eredetû tumorokat különböztetett meg [2]. Az előbélből származik a gyomor-, a duodenum- és a bronchuscarcinoid, a középbélból a jejunumból, ileumból, appendixból és a vastagbél kezdeti szakaszából kiinduló carcinoid, míg a hátsóbélből a vastagbél utolsó szakaszából és rectumból származó carcinoid. Sajnos, ez a felosztás nem mindig tükrözi a klinikai lefolyást, azonos csoportba sorolt tumorok változatos képet mutathatnak. İgy például a MEN-1-szindróma (multiplex endokrin neoplasia l-es típus) részjelenségeként kialakuló gyomorcarcinoid viszonylag enyhe lefolyású, míg a sporadikus gyomorcarcinoid agresszív, metasztatizáló daganat.

A WHO (World Health Organization) ezért a szövettani jellemzók és a kórlefolyást, kimenetelt figyelembe véve, a mindennapi klinikai gyakorlat számára hasznos osztályozást alkotott [3], amely figyelembe veszi a malignus potenciált is (1. táblázat). A jól differenciált neuroendokrin tumort „klasszikus carcinoid”, a jól differenciált neuroendokrin carcinomát pedig gyakran „malignus carcinoid" elnevezéssel illetik.

\section{Kóreredet}

A neuroendokrin daganatok kóreredete, a háttérben álló kórfolyamatok javarészt ismeretlenek. A neuroendokrin sejtek alkotják a legtöbb hormontermelő sejtet a szervezetben: a tápcsatorna neuroendokrin sejtjei multipotens őssejtből származnak, s nem neuralis sejtek migrációja révén alakulnak ki, ahogyan korábban gondolták. A differenciálódás pontos folyamata, a szabályozómechanizmusok többsége ismeretlen. A gyomor-bél rendszerben legalább 13 különböző neuroendokrin sejt ismert, amelyek különböző aminokat, peptideket, hormonokat, vazoaktív anyagokat termelnek (szerotonin, 
1. táblázat | A neuroendokrin tumorok WHO-beosztása

\begin{tabular}{ll}
\hline Tumortípus & Szövettani jellemzők \\
\hline Jól differenciált neuroendokrin & - Trabecularis, szigetszerú \\
tumor & szerkezet \\
- benignus & - Minimalis sejtpleomorphia \\
- bizonytalan malignus potenciál & - Alacsony mitotikus aktivitás \\
Jól differenciált neuroendokrin & - Pontszerú necrosis \\
carcinoma & - Növekedett sejtpleomorphia \\
& - Növekedett mitotikus aktivitás \\
Rosszul differenciált & - Többszörös necrosis \\
neuroendokrin carcinoma & - Kifejezett sejtpleomorphia \\
& - Magas mitotikus aktivitás \\
\hline
\end{tabular}

szomatosztatin, hisztamin, gasztrin, motilin, szekretin) és vesiculumaikban raktároznak [4]. A vesiculumok jellemző fehérjéje a kromogranin-A, amely a neuroendokrin tumorok jellemző markere. Az enterokromaffin(EC-) sejt a vékonybél, míg az enterokromaffinszerú sejt (enterochromaffin-like cell, ECL) a gyomor jellemző neuroendokrin sejtje. Ez utóbbi a gyomor antralis G-sejtjeiból származó gasztrin hatására hisztamint szabadít fel, amely a gyomor parietalis sejtjeire hatva részt vesz a savelválasztásban [5].

A neuroendokrin daganatok eredetével kapcsolatban javarészt állatkísérletes adatok és humán NET-sejtvonalak vizsgálati eredményei állnak rendelkezésünkre. Ezek a megfigyelések azonban közvetlenül nem hasznosíthatók a klinikai gyakorlatban, egyértelmű következtetéseket nem lehet levonni. Egerekben az SV40 vírus-Tantigén az inzulin gén-promoter szabályozása mellett hasnyálmirigy-szigetsejtes tumort indukált, N-myc-expressziót mutató zebrahalakban hasnyálmirigy-carcinoidot idéztek elő [6]. Előbél-eredetü NET esetén gyakran igazolható a 610 aminosavból álló fehérjét kódoló menin gén deléciója vagy mutációja. Ezek a génhibák tehetők felelőssé a MEN-1-szindróma többségében a daganatképződésért. Egy másik örökletes tumorszindrómára, a neurofibromatosis l-es típusára (NF1) jellemző a duodenumcarcinoid. Bár ezekben a daganatokban gyakran mutatható ki szomatosztatintermelés, ezzel összefüggésbe hozható tünetek ritkán jelentkeznek [7]. Hátsóbél-eredetû́ neuroendokrin daganatokban a transzformáló növekedési faktor- $\alpha$ (TGF- $\alpha)$ és az epidermalis növekedési faktor (EGF) expresszióját is igazolták [4]. Középbél-eredetú carcinoid tumorokban a 18-as kromoszóma delécióját találták gyakorinak [8]. Annak ellenére, hogy a genetikai háttér kutatása erőteljes, a menin gén szerepén kívül napjainkig kevés összefüggés tisztázott.

\section{Epidemiológia}

A neuroendokrin daganat az adenocarcinománál ritkább daganat: incidenciája 2,5-5/100 000 lakos [4, 9]. Az Egyesült Államokból származó, több mint húszezer NET-beteg adatait tartalmazó „Surveillance Epidemi- ology and End Results (SEER, 1973-2004)" adatbázis szerint az incidencia a daganat típusától függően 3-10\%kal nő évente [10]. Míg 1994-ben a neuroendokrin daganatok a malignus tumorok 0,75\%-át, 2004-ben már 1,25\%-át alkották. Az incidencia növekedését részben a diagnosztikus módszerek fejlődése, másrészt vélhetően a körültekintő orvosi tevékenység, az ismeretek bővülése magyarázhatják. A NET előfordulása növekszik a korral, fó kiindulási helye az emésztőrendszer (62-67\%) és a tüdő (22-27\%). Metasztatikus betegség 12-24\%-ban alakul ki.

\section{Szervspecifikus jellemzők}

A carcinoid tumorok klinikai tünetei, a kórlefolyás és prognózis változatos, függően a daganat lokalizációjától.

\section{Bronchopulmonalis neuroendokrin daganat}

A tüdődaganatok közel 20\%-át teszi ki, a bronchopulmonalis epitheliumból származnak. A morfológiai, immunhisztokémiai sajátságok alapján négy alcsoport különíthető el: típusos carcinoid tumor, atipusos carcinoid, nagysejtes neuroendokrin carcinoma és kissejtes tüdörák. Ez utóbbi a leggyakoribb bronchopulmonalis NET. A leggyakoribb tünet a köhögés, vérköpés, pneumonia, a tumor elhelyezkedésétől és méretétől függően [11]. Kevesebb mint 5\%-ban alakulnak ki a hormontermelés következtében jellegzetes tünetek, úgymint carcinoid szindróma, Cushing-szindróma, acromegalia vagy vazopresszintúltermelés (syndrome of inappropriate $\mathrm{ADH}$ secretion, SIADH).

A carcinoid szindróma jellegzetes klinikai tünetegyüttes, amelyet bőrpír (flush), hasmenés, jobbszívfélelégtelenség és nehézlégzés jellemez. A tünetegyüttes egyéb lokalizációjú carcinoid tumor esetén is kialakulhat, a szerotonin mellett egyéb vazoaktív anyagok jutnak a keringésbe, amelyek felelősek a tünetekért. A jobbszívfél-elégtelenség feltételezett kórfolyamata szerint a vazoaktív és fibrosist provokáló anyagok a vena cava inferioron keresztül a tricuspidalis és pulmonalis billentyúkön plakk-képződést indukálnak, de egyéb hormonális mediátorok (IGF-I) oki szerepe is felmerült [12]. Típusos carcinoid szindróma májmetasztázisok esetén gyakrabban alakul ki. Ez arra utal, hogy a tünetekért felelös anyagokat a máj lebontja, májáttét esetén azonban ez a lebontás elmarad. A nagysejtes neuroendokrin carcinoma és kissejtes tüdőrák agresszív, gyorsan metasztatizáló daganat, a prognózis nagyon rossz, míg az ötéves túlélés típusos carcinoid esetén jó, 90\% [11].

\section{Gyomor neuroendokrin daganat}

A gyomorcarcinoid három típusa különböztethető meg. Az 1-es típusú gyomorcarcinoid (az összes gyo- 
morcarcinoid 70-80\%-a) autoimmun gastritis mellett alakul ki, nőkben gyakoribb. Az achlorhydria következményeként hypergastrinaemia alakul ki, az atrophiás gastritisben szenvedők közel 5\%-ában alakul ki gyomorcarcinoid. Prognózisa jó, az ötéves túlélés 90\% felett van. A 2-es típusú carcinoid közepes malignitású, az esetek 30\%-ában metasztatizál. Gastrinoma, Zollinger-Ellison-szindróma (ZES) gyakran jelen van, különösen MEN-1-szindrómával társuló esetekben. Többnyire többszörös elhelyezkedésű a daganat. A prognózis változó, azonban rendszerint viszonylag jó. A 3-as tipusú gyomorcarcinoid a daganatok 15\%-át alkotja, leginkább malignus; metasztázis az esetek több mint 50\%-ában kialakul [13]. A gyomorcarcinoidokat legtöbbször más ok miatt végzett felső endoszkópos vizsgálat során, véletlenül fedezik fel, sokszor teljesen tünetmentesek [13]. A leggyakoribb tünet a hasi fájdalom, hányinger vagy tápcsatornai vérzés - ez utóbbi a 3-as típus esetén fordul elő a leggyakrabban. Ritkán carcinoidszindróma is jelen lehet, azonban a 3-as típusú carcinoid esetén a tünetekért nem a szerotonin, hanem az 5-hidroxitriptofán a felelős: a hidroxitriptofánt szerotoninná alakító dopa-dekarboxiláz enzim múködése ugyanis károsodott. A tünetegyüttest „atípusos carcinoid szindrómának" is nevezik: a flush sokkal kifejezettebb, lilásvörös, gyakran az egész felső testre kiterjed, kifejezett könnyezés, oedema, bronchoconstrictio jellemzi [14].

A gyomorcarcinoidok kialakulásában a hypergastrinaemia oki szerepe felmerül, tartós savszekréciógátló kezelés következtében kialakuló carcinoid tumort azonban emberben napjainkig nem bizonyítottak.

\section{Vékonybél neuroendokrin daganat}

A tápcsatornából kiinduló neuroendokrin daganatok közül a leggyakoribb, az összes neuroendokrin tumor közel negyede itt található [10]; a vékonybél leggyakoribb daganata. Az ileumban, elsősorban annak distalis részén 6-8-szor gyakrabban fordul elő, mint a duodenumban vagy jejunumban [9]. A tünetek gyakran a 6. vagy 7. évtizedben jelentkeznek hasi fájdalom vagy bélelzáródás formájában. A bélelzáródást a mesenterium felé növekvő tumor és a carcinoiddal együttjáró kifejezett fibrosis okozza, amely a vékonybél-carcinoid egyik jellemző tünete. Májmetasztázis esetén carcinoidszindróma gyakran kialakul.

\section{Appendix neuroendokrin daganat}

A féregnyúlvány leggyakoribb tumora: általában 50-60 éves kor között diagnosztizálják, más ok miatt végzett mütét során [15]. A betegek többsége tünet- és panaszmentes, amelynek oka az lehet, hogy a daganatok egy része elzáródást nem okoz. A nagyobb tumorok azonban elzáródást, következményes heveny appendicitist okozhatnak. A féregnyúlvány alapjától távolabbi el- helyezkedésű, l cm-nél kisebb daganatok prognózisa kifejezetten jó. A tumorméret és a prognózis szorosan összefügg, a nagyobb méretü daganatok kimenetele rosszabb [16]. Az 5 éves túlélés átlagosan 70\% körül van.

\section{Vastagbél neuroendokrin daganat}

A vastagbéldaganatok mindössze $1 \%$-át teszi ki, a tápcsatorna neuroendokrin daganata ritkán alakul ki a vastagbélben, elsősorban a coecumban. A tünetek a vastagbél adenocarcinomáihoz hasonlítanak: fogyás, hasi diszkomfort, fájdalom, a székelési szokás megváltozása, vérzés jelentkezhetnek. Prognózisuk rossz, ennek oka lehet, hogy a diagnózis megállapításakor a betegek kétharmadában már lokális vagy távoli metasztázisok vannak jelen [12].

\section{Rectum neuroendokrin daganat}

A kolonoszkópia növekvő térhódítása miatt egyre gyakrabban fedezik fel véletlenszerüen a daganatot, ugyanis többnyire nem okoz tünetet. A panasz általában alhasi fájdalom, székrekedés vagy vérzés lehet. Típusos carcinoidszindróma ritkán jelentkezik, a daganat ugyanis elsősorban nem szerotonint, hanem glükagont termel [17]. Prognózisa rendszerint jó, az 5 éves túlélés 80\% felett van.

\section{Diagnózis}

A neuroendokrin daganatok általában lassan növekszenek, sokszor teljesen tünetmentesek, ami nehezíti felismerésüket. Más esetben igazolt metasztázis esetén a primer tumor lokalizálása jelent problémát. A metasztatizáló daganatok $\sim 10 \%$-ában a primer daganat a részletes klinikai vizsgálatok ellenére rejtve marad.

Az elmúlt években a képalkotó és laboratóriumi diagnosztika fejlődése, új markerek használata segíti a kórisme mielőbbi felállítását. A diagnosztika fó pillérei a laboratóriumi és képalkotó vizsgálatok.

\section{Laboratóriumi vizsgálatok}

\section{5-HIAA}

A szerotoninlebomlás termékének, az 5-hidroxi-indolecetsav (5-HIAA) 24 órás gyújtött vizeletből történő meghatározása régóta a diagnosztika alapja. Szerotonintermelő daganatok esetén a vizsgálat fajlagossága nagy (100\%), érzékenysége kisebb (73\%) [18], azonban nem funkcionáló daganatok esetén értéke normális lehet (3-15 mg/24 h). Carcinoidszindrómában nagyon érzékeny diagnosztikus módszer; a tünetek súlyossága és a vizeletben mért 5-HIAA mennyisége szoros összefüggést mutat. Klinikai adatok szerint a tartósan megnövekedett 5-HIAA és a carcinoid szívbetegség is szorosan 
összefügg [19]. A 24 órás vizeletgyújtésre a szerotonin napszaki ingadozása miatt van szükség. A vizeletben az 5-HIAA mennyisége növekedhet coeliakia vagy Whipplekór esetén is, és bizonyos ételek (banán, kivi, avokádó, földimogyoró, paradicsom) és gyógyszerek (acetaminophen, naproxen) is álpozitív eredményt okozhatnak. Kétséges esetben a vizelet vagy a vérlemezke szerotoninvagy egyes peptidhormonok (substance P) meghatározása is segíthet a diagnózisban, de ezek hozzáférhetősége korlátozott.

\section{Kromogranin-A (CgA)}

A granincsalád legismertebb tagja, a kromogranin- $A$ szekretoros fehérje, amelyet először a mellékvesevelöállományból izolálták. A kromogranin-B-t patkánymellékvesében fedezték fel, míg a család harmadik tagját, a kromogranin-C-t (vagy szekretogranin $I I-\mathrm{t}$ ) a hypophysis mellső lebenyében. A graninok legfontosabb intracelluláris feladata a szekretoros granulumok kialakítása, a hormonok elkülönítése, s ebben a $\mathrm{CgA}$ elsőrendű szerepet játszik. A CgA-expresszió károsodása a prohormonok termelődésének szabályozási zavarát és a szekretoros fehérjék mennyiségének csökkenését okozza [20]. A graninok mint prohormonok több hasítási hellyel rendelkeznek különböző endopeptidázok számára, ennek eredményeként további aktív peptidek képződnek. A CgA-ból származó pancreastatin állatkísérletben hyperglykaemiát okoz, gátolja a glükózindukált inzulinfelszabadulást a pancreas béta-sejtjeiból [21]. A CgA-ból származó vasostatin vasoconstrictiót gátló hatása mellett a simaizomsejtekre és fibroblast-adhézióra kifejtett hatását is leírták. A CgA-származék catestatin a sympathicoadrenalis rendszer katecholaminelválasztásának egyik szabályozója, egyes adatok szerint az alacsony catestatinszint összefügg a növekedett adrenalinelválasztással és a fokozott presszorválasszal, ami hy pertoniához vezethet [22].

A szérum-CgA-vizsgálatot napjainkban széles körben használják a neuroendokrin daganatok diagnosztikájában, emellett a követés során is hasznos $[23,24]$. Metasztatizáló tumor jelentős CgA-növekedést okozhat, így a vizelet-5-HIAA mellett az egyik legfontosabb diagnosztikai módszer. A vizelet-5-HIAA-vizsgálathoz képest előnye, hogy a szérum CgA-szintje nem funkcionáló neuroendokrin daganatok esetén is növekedhet. A neuroendokrin tumorok mellett azonban más daganatok vagy kórállapotok is szérum-CgA-szint-növekedéshez vezethetnek. Prosztatarák esetén mind a diagnózisban, mind a követésben alkalmazható, akár normális prosztataspecifikus antigén (PSA) esetén is [25]. Emlórák esetén is beszámoltak növekedett CgA-szintről, diagnosztikai és prognosztikus értéke azonban ilyen esetekben még kérdéses [26]. Mellékpajzsmirigybyperplasia, a pajzsmirigy C-sejtes hyperplasiája is CgAnövekedést okozhat. A CgA eliminációja a vesén át történik, ezért veseelégtelenség önmagában növeli a szérum-CgA-szintet. Súlyos veseelégtelenség akár a neu- roendokrin daganatoknál észlelt nagyon magas $\mathrm{CgA}$ szintet okozhat, ezért a vesefunkciót mindig figyelembe kell venni a CgA értékelésekor. Májelégtelenség szintén CgA-növekedést okozhat, ahogyan súlyos szivelégtelenség is, vélhetően a sympathicoadrenalis rendszer másodlagos aktivációjának következményeként. Hypoanaciditás, amely többek között atrophiás gastritis vagy hatékony savszekréció-gátló kezelés (például protonpumpagátló - PPI - kezelés) eredményeként alakulhat ki, másodlagos hypergastrinaemiát okoz, s ez a gyomor ECL-sejtjeit serkentve növeli a CgA-szintet [27]. A PPI-szerek világszerte elterjedtek, ezért alkalmazásukat mindig figyelembe kell venni a $\mathrm{CgA}$-szint értékelésekor. Saját vizsgálatunkban igazoltuk, hogy néhány napos gyógyszerelhagyás után a CgA-szint szignifikáns módon csökken, s így a PPI-szerek átmeneti felfüggesztésével elkerülhető az álpozitív eredmény [28].

A szérum-CgA-meghatározás előnye a vizelet-5HIAA mérésével szemben, hogy a vizsgálat egyszerúbb; szérumszintjét étrendi tényezők kevésbé befolyásolják; hormonálisan inaktív daganatok kimutatására is alkalmas; a szérumszint jól összefügg a daganattömeggel és követésre is hatékonyan használható [29].

\section{Pancreaspolipeptid (PP)}

A neuroendokrin tumorok nem specifikus markere, azonban érzékenysége viszonylag kicsi (57\% nem funkcionáló daganat esetén), fajlagossága valamivel nagyobb (81\%) [30]. Ha meghatározását a CgA-val együtt végzik el, érzékenysége jelentősen nő, nem funkcionáló daganatok esetén 94\% [30].

\section{Neuronspecifikus enoláz}

A neuralis, neuroectodermalis eredetü sejtek jellemző enzime. Kissejtes tüdőrákban, prosztatarákban és pajzsmirigyrák esetén is fontos diagnosztikus eszköz. Bár érzékenysége közel 100\%, fajlagossága meglehetősen alacsony.

\section{Endoszkópia}

A gyomor-bél rendszer neuroendokrin daganatait számos esetben véletlenszerűen, más ok miatt végzett vizsgálat kapcsán fedezik fel. Felsó panendoszkópia során a gyomorcarcinoidok általában kis polipszerú képletként láthatók, az l-es vagy 2-es típus esetén többszörösek lehetnek, és csoportosan helyezkednek el, míg a 3-as típusra a szoliter megjelenés jellemző. Kolonoszkópia során leggyakrabban a coecumban ismerik fel a daganatot, a vastagbél többi részén előfordulása ritkább. Az endoszkópos ultrahang (endoscopic ultrasound, EUS) a gyomor- és nyombélcarcinoidok fontos diagnosztikus eszköze, érzékenysége meghaladja a hagyományos ultrahangét, és a kis tumorok $(2-3 \mathrm{~mm})$ felismerését is lehetővé teszi. A nyirokcsomó- és májáttétek kimutatásában is hasznos lehet, bár ezzel kapcsolatban jelenleg kevés adat áll rendelkezésünkre [31]. A kapszulaendosz- 
kópia (capsule endoscopy - CE) viszonylag új módszer, amelynek jelentőségét az adja, hogy lehetővé teszi a vékonybél teljes áttekintését. Az eddigi adatok alapján úgy tünik, hogy érzékenysége meghaladja az enteroszkópiáét (42\% vs. 76\%). Az enteroclysis jelentősége korlátozott, elsősorban előrehaladott, nagy tumorok esetén hasznos. Bár multidetektoros CT-vel együtt alkalmazva a találati arány nagyobb lehet és igazolható a bélfalra illetve a környező szövetekre terjedés mértéke is, más vizsgálóeljárások e módszert háttérbe szorították [32].

A bronchopulmonalis carcinoidok bronchoszkópia során általában vöröses-barnás színű, sima felszínú tumorként jelennek meg. A daganat gyakran hypervascularizált, nem ritka a mintavételt követő kifejezett vérzés [11].

\section{Képalkotó vizsgálatok}

A CT-t és MRI-t évek óta használják a topográfiai diagnózishoz. Emésztőrendszeri carcinoid daganat esetén jellegzetes CT-kép a fibrosist, meszesedést tartalmazó képlet. Több vizsgálat adata szerint a két vizsgálómódszer között nincs lényeges különbség: a CT találati aránya 70-100\%, míg az MRI-é 67-81\% között van.

A pozitronemissziós tomográfia (PET) eljárás lényege, hogy a daganatos sejtek glikolítikus aktivitása nagy. A vizsgálathoz több jelölőanyagot használnak, a legelterjedtebben a fluorodezoxi-glükózt ( $\left.{ }^{18} \mathrm{FDG}\right)$, ezzel viszont a találati arány meglehetősen alacsony, amelyet a carcinoid daganatokra általában jellemző viszonylag alacsony proliferációs index magyarázhat. Az FDG-PETCT így a kifejezetten proliferáló, agresszív daganatok diagnosztikájában lehet hasznos. A ${ }^{11} \mathrm{C}-5$-hidroxitriptofán $\left({ }^{11} \mathrm{C}-5-\mathrm{HT}\right)$ szerotoninprekurzorral végzett vizsgálat azonban igen hatékonynak bizonyult az alacsony proliferációjú neuroendokrin daganatok kimutatására. Egy vizsgálat adatai szerint a betegek 95\%-ában lehetett azonosítani a daganatot ezzel a módszerrel, s az esetek 58\%-ában a vizsgálat több eltérést írt le, mint más képalkotók (CT és szomatosztatinreceptor-szcintigráfia SRS) [33].

A szomatosztatinreceptor-szcintigráfia (SRS) a carcinoid daganatok kórismézésének legelterjedtebb képalkotó módszere. A neuroendokrin daganatok az ismert öt szomatosztatinreceptor közül a 2-es és 5-ös típust expresszálják a legnagyobb mértékben. Így a radioaktív izotóppal jelölt szomatosztatin-analóg octreotid alkalmazásával (111indium-octreotid) a tumor kimutatható, a módszer érzékenysége $90 \%$-os. Metasztatizáló daganatok esetén az áttétek kimutatására az egyik legérzékenyebb módszer. Pozitivitása esetén nagy a valószínúsége annak, hogy a daganat érzékeny szomatosztatin-analóg terápiára. Napjainkban azonban a gyors, háromfázisú (natív, artériás és vénás fázis) helicalis CT-vizsgálatok miatt jelentősége csökkent rosszabb szövettani felbontóképessége, nem jobb specificitása és a vizsgálat költsége miatt [34].
A ${ }^{123} I$-metajódbenzilguanidin ( $\left.{ }^{123} I-M I B G\right)$ szcintigráfiát elsősorban a phaeochromocytoma diagnózisában alkalmazzák, azonban irodalmi adatok alapján a carcinoid tumorok közel 70\%-a szintén halmozza az anyagot, így a tumor felismerhető. A primer tumor és metasztázisok találati aránya egyes vizsgálatok szerint azonban csak $~ 50 \%$ [35].

A csontszcintigráfia az áttétek kimutatásában lehet hasznos, amely a neuroendokrin daganatok 10\%-ában alakul ki. Több vizsgálat eredménye szerint a módszer érzékenysége jó, a találati arány $90 \%$ vagy a feletti.

\section{Kezelés}

\section{Sebészi kezelés}

A daganat eltávolítása a kezelésben elsődleges. A sebészi beavatkozás lehet kuratív vagy palliatív: a mútétnek a metasztatizáló neuroendokrin daganat esetén is helye van, hiszen a tumor megkisebbítése, a metasztázisok eltávolítása egyértelmûen javítja az életminőséget. Gyomorcarcinoid l-es típusa esetén endoszkópos eljárás (polypectomia, mucosareszekció) is alkalmazható, 2-es típus esetén gastrectomiára lehet szükség, a 3-as típusban radikális mútétre kerül sor. A vékonybéldaganatok mútéti eljárása függ a tumormérettől, lokalizációtól és a metasztázisok jelenlététól. Az 1 cm-t meghaladó daganatok radikálisabb mútéti eltávolítást igényelnek. Az appendix daganata esetén az $1 \mathrm{~cm}$-nél kisebb tumorok appendectomia révén eltávolíthatóak, a $2 \mathrm{~cm}-\mathrm{t}$ meghaladó tumorok esetén (figyelembe véve a sokkal agresszívebb kimenetelt) több szaktekintély jobb oldali hemicolectomia elvégzését javasolja [36]. A vastagbéldaganatok $\sim 50 \%$-ában nyirokcsomó- vagy májmetasztázis igazolható, ezért a hemicolectomia, mesenterialis reszekció a javasolt módszer. A rectumdaganatok - a vakbélhez hasonlóan - mütéti módszere a tumormérettől függ; a 2 cm-t meghaladó tumorok radikális eltávolítása szükséges.

A bronchopulmonalis carcinoid tumorok közül típusos carcinoid, centrális lokalizáció esetén egyértelmúen konzervatív reszekció a választandó eljárás, az atípusos carcinoid mútéti megoldásának módja azonban ellentmondásos. Egyesek elegendőnek tartják a konzervatív eljárást, mások viszont agresszívebb módszert (nyirokcsomó-eltávolítást, kiterjesztett mütétet) javasolnak [11].

Nem áll rendelkezésünkre olyan adat, amely jól differenciált neuroendokrin daganat kuratín sebészi beavatkozást követően adjuváns szisztémás kemoterápiás vagy radioizotópkezelést tenne szükségessé. Minden betegnél, aki emésztőrendszeri carcinoid miatt mütétre kerül, javasolt a profilaktikus cholecystectomia mérlegelése is, amely mérsékli a szomatosztatin-analógok biliaris toxikus hatását és kivédi a kémiai cholecystitist, amely transarterialis kemoembolizáció esetén (TACE) alakulhat ki. 
A citoreduktív sebészet palliatín eljárás: a tumorméret csökkentése, a metasztázisok megkisebbítése révén javul az életminőség. Egy metaanalízis szerint a részleges hepatectomia során az 5 éves túlélés 71\%-os volt malignus daganat esetén, s a betegek 86\%-ában a carcinoid szindróma is megszűnt 4-120 hónapig [37]. A citoreduktív sebészet több módszert egyesíthet, úgymint a rádiófrekvenciás ablatio, krioterápia, mikrohullámú kezelés vagy az arteria hepatica embolisatiója/ kemoembolisatiója - ez utóbbi módszerrel kapcsolatban szintén kedvező tapasztalatokról számoltak be [38].

\section{Gyógyszeres kezelés}

\section{Szomatosztatin-analógok}

Carcinoidszindrómában a szomatosztatin-analógok (SSA) alkalmazása, jelenlegi ismereteink szerint, a leghatékonyabb gyógyszeres kezelési mód. Szelektíven a szomatosztatin-receptorhoz kötődve mérséklik a tüneteket, csökkentik a vizeletben az 5-HIAA ürítését, de közvetlen tumorgátló hatásuk is bizonyított. Részleges vagy teljes daganatregressziót 5-10\%-ban figyeltek meg, többnyire hormontermelő neuroendokrin daganatok esetében, míg progressziómentes állapot 40-50\%-ban fordult elő. Egy újabb vizsgálat szerint az SSA mind hormontermelő, mind nem funkcionáló metasztatikus neuroendokrin daganatos betegekben növelte a progressziómentes időszakot [39]. Hazánkban két készítmény áll rendelkezésünkre: az octreotid és a lanreotid, ezek tartós hatású formában is elérhetőek, amely az adagolást könnyíti és javítja a compliance-t. Napjainkban a tartós hatású készítmények adagolása elfogadott (octreotid LAR: 10, 20 vagy $30 \mathrm{mg} 4$ hetente; lanreotid PR: $30 \mathrm{mg} 7,10$ vagy 14 naponta; lanreotid autogel: 60, 90 vagy $120 \mathrm{mg} 4$ hetente). A kezelés kezdetén rövid hatástartamú, subcutan octreotid adására is szükség lehet a megfelelő vérszint eléréséig [40]. A készítmények tolerálhatósága kiváló, mellékhatásaik viszonylag ritkák és rendszerint enyhék. A tartós hatású SSA-készítmények a kényelmes adagolási mód és a tartós terápiás hatás miatt jelentősen javítják a carcinoidszindrómás betegek életminőségét.

Egy új szomatosztatin-analóg, a pasireotid (SOM 230) hatékonyságát jelenleg II. fázisú klinikai vizsgálatokban tanulmányozzák. A pasireotid receptorkötődési spektruma szélesebb (a 2-es és 5-ös receptorokon kívül az 1-es és 3-as receptorokhoz is nagy affinitással kötődik), ezért klinikai hatékonysága várhatóan felülmúlja a jelenleg rendelkezésre álló készítményekét. A gyógyszerfejlesztés további új vívmánya egy úgynevezett hibrid molekula, a dopastatin (BMI-23A387), amelynek sajátossága, hogy szomatosztatin-analóg tulajdonságán kívül D2-dopamin-receptor-agonista hatással is rendelkezik.

\section{Interferon}

$\mathrm{Az}$ interferon-alfa a tumorsejtek fehérje- és hormonszintézisének, az angiogenesis gátlása és az immunrendszer serkentése révén fejti ki daganatellenes hatását. Elsősorban lassan növekvő neuroendokrin daganatok esetén alkalmazható, átlagos dózisa 3-5 millió egység heti 3 alkalommal. A pegilált forma adagja rendszerint 75-150 $\mu \mathrm{g}$ subcutan, az adagot azonban egyénre szabottan kell beállítani. Bár az interferonkezelés eredményei biztatók, számos lehetséges mellékhatása (neutropenia, hepatotoxicitas, depresszió, autoimmun betegségek) hátrányt jelentenek. Alkalmazása ezért csak szigorú ellenőrzés mellett történhet. Egy vizsgálat eredményei szerint interferon- és octreotidkezelés együttes alkalmazása mérsékelte a daganatnövekedést, azonban a túlélést nem befolyásolta [41].

\section{Kemoterápiás szerek}

A neuroendokrin tumorok kezelésére többféle kemoterápiás készítményt kipróbáltak. Ezek közül például az etoposid és cisplatin, vagy hasnyálmirigy NET esetén a streptozotocin és 5-fluorouracil/doxorubicin kombináció alkalmazásával a tumor megkisebbedéséról számoltak be [4, 42]. A kemoterápiára reagáló esetek aránya azonban a különböző vizsgálatokban meglehetôsen változékony volt, ami összefügghet azzal, hogy a különböző tanulmányokban eltérô típusú és grádusú tumorokat vizsgáltak. A streptozotocin és doxorubicin/5-fluorouracil kis vagy közepes proliferációjú daganatok, a cisplatin és etoposid kombináció anaplasticus vagy rosszul differenciált daganatok esetén javasolt.

A glioblastoma kezelésére régebb óta alkalmazott temozolomid II. fázisú klinikai vizsgálatban neuroendokrin daganatokban is hatékonynak bizonyult; egy retrospektív vizsgálat előrehaladott stádiumú neuroendokrin daganatos betegek 14\%-ában daganatregressziót és 53\%ában progressziómentes állapotot észlelt [43]. Kedvező hatást figyeltek meg a temozolomid és thalidomid együttadásával is [44].

\section{Tirozinkináz-gátlók és tirozinkináz-ellenes antitestek}

A tirozinkináz-receptorokat gátló szereket - más tumorokhoz hasonlóan - neuroendokrin daganatok kezelésére is kipróbálták, a tapasztalat azonban még csekély. $\mathrm{Az}$ epidermal growth factor receptort (EGFR) gátló gefitinib II. fázisú klinikai vizsgálatban nem bizonyult hatékonynak progresszív, metasztatizáló NET-betegekben [45]. A platelet-derived growth factor receptor (PDGFR) és c-kit-gátló imatinib szintén szerény hatékonyságúnak bizonyult [46]. A vascular endothelial growth factor (VEGF) és egyéb tirozinkinázokat gátló sunitinib és sorafenib hatékonysága II. fázisú klinikai vizsgálatban az előzőekben említett tirozinkináz-gátlókhoz képest kedvezőbbnek tûnt [47]. III. fázisú klinikai vizsgálat szerint a sunitinib a progressziómentes túlélést 11,4 hónapra növelte a placebóval kezelt bete- 
gekben észlelt 5,5 hónaphoz képest; alcsoport-analízis alapján minden csoportban növelte a progressziómentes túlélést [48]. II. fázisú klinikai vizsgálatban a VEGFellenes monoklonális antitest bevacizumab és octreotid együttes adása eredményesebbnek bizonyult az octreotid + interferon kombinációval szemben [49]. Citosztatikus szerekkel vagy mTOR-gátlóval együtt adva is hatékonynak bizonyult [50].

\section{mTOR-gátlók}

A mammalian target of rapamycin (mTOR) -gátló temsirolimus egy II. fázisú klinikai vizsgálatban progresszív, előrehaladt stádiumú neuroendokrin daganatos betegek 6\%-ában részleges daganatregressziót és 58\%-ában progressziómentes állapotot váltott ki; az átlagos progressziómentes időszak 6 hónap volt [51]. A viszonylag kedvező hatékonyság mellett gyakran észleltek mellékhatást. Figyelemre méltó eredményról számoltak be az everolimus és a tartós hatású octreotid együttes adásakor; II. fázisú klinikai vizsgálatban előrehaladott stádiumú neuroendokrin daganatos betegek 20\%-ában daganatregressziót és 70\%-ában progressziómentes állapotot figyeltek meg; az átlagos progressziómentes idő 14 hónap, a 3 éves túlélési idő 78\% volt [52].

\section{Peptidreceptor radionuklid kezelés}

A neuroendokrin daganatok kezelésében az utóbbi években az izotóppal ( ${ }^{90}$ ittrium, ${ }^{177}$ lutécium) kapcsolt szomatosztatin-analógok bevezetése jelentette az egyik legjelentősebb előrelépést [53]. A kezelés akkor végezhető el, ha szomatosztatinreceptor-szcintigráfiás vizsgálattal a daganatban izotópdúsulás mutatható ki. Az izotóppal jelölt szomatosztatin-analógok nagy specificitással kötődnek a carcinoid daganatok sejtfelszíni szomatosztatinreceptoraihoz, majd internalizáció révén a daganatsejtekbe bejutva sejtkárosító hatást fejtenek ki. A kezelést progresszív, előrehaladott stádiumú, többszörös áttétekkel társuló daganatok esetében alkalmazzák. Kezdetben a ${ }^{111}$ indium-octreotid kezelést fejlesztették ki, majd a ${ }^{90}$ Y-DOTA-D-Phe-Tyr-octreotid $\left({ }^{90} \mathrm{Y}\right.$-DOTA-TOC) és ${ }^{177} \mathrm{Lu}-\mathrm{DOTA}-\mathrm{TOC}$ kezeléssel számoltak be kedvező eredményekről. ${ }^{90} \mathrm{Y}$-DOTA-TOC kezeléssel figyelemre méltó tumorgátló hatást (a betegek 2\%-ában teljes, 22\%-ában részleges és 12\%-ában kisfokú daganatregresszió, míg 49\%-ukban stabil, progressziómentes állapot), túlélést ( 2 éves átlagos túlélés 76\%) és tüneti javulást (a betegek 83\%-ában) figyeltek meg [54]. Mellékhatásként leukopenia, pancytopenia és vesekárosodás fordulhat elő.

A neuroendokrin daganatok egy részében - a phaeochromocytomák többségéhez hasonlóan - ${ }^{123}$ I-MIBG szcintigráfiával izotópdúsulás észlelhető. Ilyen esetekben ${ }^{131}$ I-MIBG kezelés végezhető; a ${ }^{131}$ I-MIBG kezelés metasztatizáló carcinoid tumoros betegek 30-40\%-ában enyhíti a klinikai tüneteket és a betegek 7-10\%-ában eredményez biokémiai javulást [55].

\section{Követés és prognózis}

A neuroendokrin daganatban szenvedő betegek tünetmentességének elérése, életminőségének javítása csak a társszakmák (sebész, onkológus, belgyógyász, endokrinológus, gasztroenterológus) összefogása révén lehet hatékony. Bár a NET alapvetően lassan növekvő daganat, nagy proliferációs rátájú ( $\mathrm{Ki}-67$ index $>5 \%$ ), rosszul differenciált tumor esetén gyors progresszióra is számítani lehet. A prognózist jelentősen befolyásolja a daganat elhelyezkedése és kiterjedtsége. Eredményes daganatreszekció esetén is a betegek tartós követése és ellenőrzése szükséges; ha a panaszok, a biokémiai markerek változnak, új tünetek jelentkeznek, vagy a képalkotó vizsgálatok kiújulást jeleznek, akkor teljes újraértékelés szükséges. A carcinoid szívbetegség korai felismerése javítja a prognózist, növekedett 5-HIAA esetén korai echokardiográfia indokolt. Az új kezelési lehetőségek még metasztatikus folyamat esetén is megteremtik az alapját az életminőség javításának.

\section{Irodalom}

[1] Ong, S. L., Garcea, G., Pollard, C. A. és mtsai: A fuller understanding of pancreatic neuroendocrine tumours combined with aggressive management improves outcome. Pancreatology, 2009, 9, 583-600.

[2] Williams, E. D., Sandler, M.: The classification of carcinoid tumors. Lancet, 1963, 1, 238-239.

[3] Kloppel, G., Perren, A., Heitz, P. U.: The gastroenteropancreatic neuroendocrine cell system and its tumors: the WHO classification. Ann. N. Y. Acad. Sci., 2004, 1014, 13-27.

[4] Modlin, I. M., Oberg, K., Chung, D. C. és mtsai: Gastroenteropancreatic neuroendocrine tumours. Lancet Oncol., 2008, 9, 61-72.

[5] Dockray, G., Dimaline, R., Varro, A.: Gastrin: old hormone, new functions. Pflugers Arch., 2005, 449, 344-355.

[6] Yang, H. W., Kutok, J. L., Lee, N. H. és mtsai: Targeted expression of human MYCN selectively causes pancreatic neuroendocrine tumors in transgenic zebrafish. Cancer Res., 2004, 64, 7256-7262.

[7] Tanaka, S., Yamasaki, S., Matsushita, H. és mtsai: Duodenal somatostatinoma: a case report and review of 31 cases with special reference to the relationship between tumor size and metastasis. Pathol. Int., 2000, 50, 146-152.

[8] Lollgen, R. M., Hessman, O., Szabo, E. és mtsai: Chromosome 18 deletions are common events in classical midgut carcinoid tumors. Int. J. Cancer, 2001, 92, 812-815.

[9] Modlin, I. M., Lye, K. D., Kidd, M.: A 5-decade analysis of 13 715 carcinoid tumors. Cancer, 2003, 97, 934-959.

[10] US National Cancer Institute. Surveillance Epidemiology and End Results (SEER) data base, 1973-2004. http://seer.cancer. gov/

[11] Gustafsson, B. I., Kidd, M., Chan, A. és mtsai: Bronchopulmonary neuroendocrine tumors. Cancer, 2008, 113, 5-21.

[12] Öberg, K.: Carcinoid tumors, carcinoid syndrome, and related disorders. In: Williams Textbook of Endocrinology. Eds: Larsen, P. R., Kronenberg, H. M., Melmed, S., Polonsky, K. S. Tenth edition. WB Saunders Co., Philadelphia, 2002, 1957-1976.

[13] Borch, K., Ahren, B., Ahlman, H. és mtsai: Gastric carcinoids: biologic behavior and prognosis after differentiated treatment in relation to type. Ann. Surg., 2005, 242, 64-73. 
[14] Oates, J. A., Sjoerdsma, A.: A unique syndrome associated with secretion of 5 -hydroxytryptophan by metastatic gastric carcinoids. Am. J. Med., 1962, 32, 333-342.

[15] Lundqvist, M., Wilander, E.: Subepithelial neuroendocrine cells and carcinoid tumours of the human small intestine and appendix. A comparative immunohistochemical study with regard to serotonin, neuron-specific enolase and S-100 protein reactivity. J. Pathol., 1986, 148, 141-147.

[16] Moertel, C. G., Weiland, L. H., Nagorney, D. M. és mtsai: Carcinoid tumor of the appendix: Treatment and prognosis. N. Engl. J. Med., 1987, 317, 1699-1701.

[17] Kulke, M., Mayer, R.: Carcinoid tumors. N. Engl. J. Med., 1999, $340,858-868$.

[18] Feldman, J. M., O'Dorisio. T. M.: Role of neuropeptides and serotonin in the diagnosis of carcinoid tumors. Am. J. Med., 1986, $81,41-48$.

[19] Norbeim, E.: Carcinoid heart disease: relationship of circulating vasoactive substances to ultrasound-detectable cardiac abnormalities. Circulation, 1988, 77, 264-269.

[20] Kim, T., Tao-Cheng, J. H., Eiden, L. E. és mtsa: Chromogranin A, an „on/off” switch controlling dense-core secretory granule biogenesis. Cell, 2001, 106, 499-509.

[21] Tatemoto, K., Efendic, S., Mutt, V.és mtsai: Pancreastatin, a novel pancreatic peptide that inhibits insulin secretion. Nature, 1986, 324, 476-478.

[22] O'Connor, D. T., Kailasam, M. T., Kennedy, B. P. és mtsai: Early decline in the catecholamine release-inhibitory peptide catestatin in humans at genetic risk of hypertension. J. Hypertens., 2002, 20, 1335-1345.

[23] Sondenaa, K., Sen, J., Heinle, F. és mtsai: Chromogranin A, a marker of the therapeutic success of resection of neuroendocrine liver metastases: preliminary report. World J. Surg., 2004, $28,890-895$

[24] Pregun, I., Gergics, P., Dabasi, G. és mtsai: Serum chromogranin A reflects regression of metastatic carcinoid during prolonged octreotide treatment. Eur. J. Gastroenterol. Hepatol., 2009, 21, 476-477.

[25] Deftos, L. J., Abrahamsson, P. A.: Granins and prostate cancer. Urology, 1998, 51, 141-145.

[26] Giovanella, L., Marelli, M., Ceriani, L. és mtsai: Evaluation of chromogranin A expression in serum and tissues of breast cancer patients. Int. J. Biol. Markers, 2001, 16, 268-272.

[27] Sanduleanu, S., Stridsberg, M., Jonkers, D. és mtsai: Serum gastrin and chromogranin A during medium- and long-term acid suppressive therapy: a case-control study. Aliment. Pharmacol. Ther. 1999, 13, 145-153.

[28] Pregun, I., Herszényi, L., Miheller, P. és mtsai: Serum chromogranin A level decreases rapidly after cessation of proton pump inhibitor therapy. Gastroenterology, 2010, 138, S-650, W1097 Abstract.

[29] Igaz P., Rácz K.: Carcinoid tumorok: sokszínú megjelenés és kezelési lehetőség. LAM, 2009, 19, 493-495.

[30] Panzuto, F., Severi, C., Cannizzaro, R. és mtsai: Utility of combined use of plasma levels of chromogranin A and pancreatic polypeptide in the diagnosis of gastrointestinal and pancreatic endocrine tumors. J. Endocrinol. Invest., 2004, 27, 6-11.

[31] Zimmer, T., Ziegler, K., Liehr, R. M. és mtsai: Endosonography of neuroendocrine tumors of the stomach, duodenum, and pancreas. Ann. N. Y. Acad. Sci., 1994, 733, 425-436.

[32] Horton, K. M., Fishman, E. K.: The current status of multidetector row $\mathrm{CT}$ and three-dimensional imaging of the small bowel. Radiol. Clin. North Am., 2003, 41, 199-212.

[33] Orlefors, H., Sundin, A., Garske, U. és mtsai: Whole-body (11) C-5-hydroxytryptophan positron emission tomography as a universal imaging technique for neuroendocrine tumors: comparison with somatostatin receptor scintigraphy and computed tomography. J. Clin. Endocrinol. Metab., 2005, 90, 33923400 .
[34] Saltz, l., Gollub, M., Reidy, D. L.: The role of octreotide imaging in detecting neuroendocrine tumors (NETs) in 2010: Do we still need it? American Association of Clinical Oncologists Meeting, 2010, Abstr. 4032.

[35] Hoefnagel, C. A., den Hartog Jager, F. C., Taal, B. G. és mtsai: The role of I-131-MIBG in the diagnosis and therapy of carcinoids. Eur. J. Nucl. Med., 1987, 13, 187-191.

[36] Fornaro, R., Frascio, M., Sticchi, C. és mtsai: Appendectomy or right hemicolectomy in the treatment of appendiceal carcinoid tumors? Tumori, 2007, 93, 587-590.

[37] Que, F. G., Sarmiento, J. M., Nagorney, D. M.: Hepatic surgery for metastatic gastrointestinal neuroendocrine tumors. Cancer Control, 2002, 9, 67-79.

[38] Bloomston, M., Al-Saif, O., Klemanski, D. és mtsai: Hepatic artery chemoembolization in 122 patients with metastatic carcinoid tumor: lessons learned. J. Gastrointest. Surg., 2007, 11, 264-271.

[39] Rinke, A., Muller, H-H., Schade-Brittinger, C. és mtsai: Placebocontrolled, double blind, prospective, randomized study on the effect of octreotide LAR in the control of tumor growth in patients with metastatic neuroendocrine midgut tumors: a report from the PROMID Study Group. J. Clin. Oncol., 2009, 27, 4656-4663.

[40] Appetecchia, M., Baldelli, R.: Somatostatin analogues in the treatment of gastroenteropancreatic neuroendocrine tumours, current aspects and new perspectives. J. Exp. Clin. Cancer. Res., 2010, 29, 19

[41] Kolby, L., Persson, G., Franzen, S. és mtsai: Randomized clinical trial of the effect of interferon alpha on survival in patients with disseminated midgut carcinoid tumours. Br. J. Surg., 2003, 90, 687-693.

[42] Kouvaraki, M. A., Ajani, J. A., Hoff, P. és mtsai: Fluorouracil, doxorubicin, and streptozocin in the treatment of patients with locally advanced and metastatic pancreatic endocrine carcinomas. J. Clin. Oncol., 2004, 22, 4762-4771.

[43] Ekehlad, S., Sundin, A., Janson, E. T. és mtsai: Temozolomide as monotherapy is effective in treatment of advanced malignant neuroendocrine tumors. Clin. Cancer Res., 2007, 13, 2986-2991.

[44] Kulke, M. R., Stuart, K., Enzinger, P. C. és mtsai: Phase II study of temozolomide and thalidomide in patients with metastatic neuroendocrine tumors. J. Clin. Oncol., 2006, 24, 401-406.

[45] Hobday, T. H. K., Donehower, R.: A phase II trial of gefitnimib in patients with progressive metastatic neuroendocrine tumors [abstract]. J. Clin. Oncol., 2006, 24, 189s.

[46] Yao, Y. C., Zhang, J. X., Rashid, A. és mtsai: Clinical and in vitro studies of imatinib in advanced carcinoid tumors. Clin. Cancer Res., 2007, 13, 234-240.

[47] Kulke, M. H., Lenz, H. J., Meropol, N. J. és mtsai: Activity of sunitinib in patients with advanced neuroendocrine tumors. J. Clin. Oncol., 2008, 26, 3403-3410.

[48] Raymond, E., Niccoli-Sire, P., Bang, Y. és mtsai: Updated results of the phase III trial of sunitinib (SU) versus placebo (PBO) for treatment of advanced pancreatic neuroendocrine tumors (NET). American Association of Clinical Oncologists Meeting, 2010, Abstr. 127.

[49] Yao, J. C., Phan, A., Hoff, P. M. és mtsai: Targeting vascular endothelial growth factor in advanced carcinoid tumor: a random assignment phase II study of depot octreotide with bevacizumab and pegylated interferon alpha-2b. J. Clin. Oncol., 2008, 26, 1316-1323.

[50] Bristi, B., Bhawna, S., Pippa, C.: Systemic therapy for neuroendocrine tumours of gastroenteropancreatic origin. Endocr. Relat. Cancer, 2010, 17, R75-R90.

[51] Duran, I., Kortmansky, J., Singh, D. és mtsai: A phase II clinical and pharmacodynamic study of temsirolimus in advanced neuroendocrine carcinomas. Br. J. Cancer, 2006, 95, 1148-1154.

[52] Yao, J. C., Phan, A. T., Chang, D. Z. és mtsai: Efficacy of RAD001 (everolimus) and octreotidé LAR in advanced low- to intermedi- 
ate-grade neuroendocrine tumors: results of a phase II study. J. Clin. Oncol., 2008, 26, 4311-4318.

[53] Kwekkeboom, D. J., Mueller-Brand, J., Paganelli, G. és mtsai: Overview of results of peptide receptor radionuclide therapy with 3 radiolabeled somatostatin analogs. J. Nucl. Med., 2005, $46,62 S-66 S$.

[54] Waldherr, C., Pless, M., Maecke, H. R. és mtsai: The clinical value of $\left[{ }^{90} \mathrm{Y}\right.$-DOTA $]$-D-Phe ${ }^{1}$-Tyr ${ }^{3}$-octreotide $\left({ }^{90} \mathrm{Y}\right.$-DOTATOC) in the treatment of neuroendocrine tumors: a clinical phase I study. Ann. Oncol., 2001, 12, 941-945.
[55] Taal, B. H., Hoefnagel, C. A., Valdés Olmos, R. A. és mtsai: Palliative effect of meta-iodobenzyl-guanidine in metastatic carcinoid tumors. J. Clin. Oncol., 1996, 14, 1829-1838.

(Pregun István dr., Budapest, Szentkirályi u. 46., 1088 e-mail: pregunistvan@yahoo.com)

\section{Tisztelt Olvasónk!}

Kórházak, egészségügyi intézmények, tudományos társaságok szakmai és továbbképző programjait, az egészségüggyel, az orvostudománnyal kapcsolatos pályázatok felhívásait, ösztöndíj-felhívásait és a kórházak, az egészségügyi intézmények pályázati hirdetményeit kedvezményes áron tudjuk közölni lapunkban.

\section{Szódíj: $25 \mathrm{Ft}+$ áfa}

Elöfizetőink hirdetéseit

70 szó terjedelemig térítésmentesen jelentetjük meg.

A hirdetés megrendelhető e-mailen, a Budai.Edit@akkrt.hu címen.

A számla kiegyenlítése átutalással vagy

a kiadó által küldött csekk befizetésével lehetséges. 